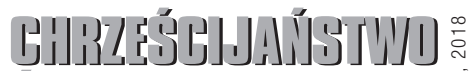 \\ SUTLITP PIITHBA
}

ZESZYTY SPOŁECZNEJ MYŚLI KOŚCIOŁA

Grzegorz Górny

\section{Aksamitny totalitaryzm, \\ czyli zapomniana przestroga Jana Pawła II}

\section{Velvet Totalitarianism, the forgotten warning of John Paul II}

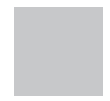

Abstrakt: Artykuł podejmuje problem konsekwencji wdrażania „programu oświeceniowego" świata bez Boga dla współczesnego liberalizmu. Rozważa, w odwołaniu do myśli współczesnych intelektualistów (jak Chantal Delsol, Vladimir Bukowski, Vaclav Havel) aktualność uwagi Jana Pawła II twierdzącego, że marksistowski kolektywizm, jest tylko "gorszym wydaniem» tego samego program, który dochodzi do głosu we współczesnych liberalnych demokracjach.

Słowa kluczowe: Totalitaryzm, Jan Paweł II, liberalizm, demokracja

Abstract: The article deals with the problem of the consequences of implementing the world's "Enlightenment program" without God for modern liberalism. With reference to the thought of modern intellectuals (like Chantal Delsol, Vladimir Bukowski, Vaclav Havel), it discusses the still up-to-date remark by John Paul II who stated that Marxist collectivism is just a "worse version" of the same program that manifests itself in modern liberal democracies.

Key words: Totalitarianism, John Paul II, liberalism, democracy

Dnia 10 czerwca 1987 r. Jan Paweł II stanął w oknie kurii krakowskiej, by porozmawiać z młodzieżą, która wypełniła szczelnie ulicę Franciszkańską wraz z przecznicami oraz okolicznymi zaułkami. Papieża powitał wyrywający się z tysięcy gardeł okrzyk: „Weź nas z sobą! Weź nas z sobą!”.

Widać było, że Ojciec Święty na moment zafrasował się. To była radykalna zmiana w porównaniu z dwoma poprzednimi pielgrzymkami w 1979 i 1983 r. Wtedy młodzi w tym samym miejscu krzyczeli do niego: „Zostań z nami!”. 
Okrzyk „Weź nas z sobą!” oznaczał, że nie widzą w Polsce przyszłości. Okres beznadziei po stanie wojennym przedłużał się. Ponad milion osób, głównie młodych, ambitnych i dynamicznych, wyemigrowało na Zachód. Większość nie wierzyła, iż komunizm upadnie, a przynajmniej, że skończy się za ich życia.

Papież podjął dialog. Mówił nie tylko do tysięcy zgromadzonych przed oknem kurii, lecz również do milionów wpatrujących się w tym momencie w ekrany telewizorów: „Nie myślcie, że tu jest najtrudniej. Jest trudno także i tam. Problemy młodzieży są wszędzie bardzo podobne i wszędzie trzeba szukać na nie mniej więcej takiej samej odpowiedzi. Ta odpowiedź jest w nas".

Jan Paweł II zaczął opowiadać, że gdziekolwiek pojawi się we Włoszech, z jakimkolwiek środowiskiem rozmawia, wszędzie młodzi użalają się na swój los. Wspomniał, że jego generacji, której młodość przypadła na mroczny czas okupacji, wcale nie było łatwiej. Każdy czas i każde miejsce stawiają człowieka przed wyzwaniami, które są mu zadane.

Dwa dni później powtórzył to przesłanie jeszcze dobitniej w swym przemówieniu do młodzieży na Westerplatte: „Każdy z Was, młodzi Przyjaciele, znajduje też w życiu jakieś swoje Westerplatte, jakichś wymiar zadań, które trzeba podjąć i wypełnić, jakąś słuszną sprawę, o którą nie można nie walczyć, jakiś obowiązek, powinność, od której nie można się uchylić, nie można zdezerterować”. Wśród słuchających papieża były osoby, które po tej mowie postanowiły, że nie wyjadą z kraju, lecz pozostaną tam, gdzie postawił ich Bóg.

Jeszcze tego samego dnia podczas Mszy na Jasnej Górze Jan Paweł II wypowiedział słowa, które wielu słuchaczy zdumiały. Choć kraj był zniewolony przez komunizm, Ojciec Święty opowiadał o „trudnym darze wolności”. Przestrzegał przed złym użyciem swobód i wyrodzeniem ich w swawolę. Nazajutrz, żegnając pielgrzymów zgromadzonych u stóp jasnogórskiego klasztoru, Jan Paweł II mówił im o dwóch rodzajach zagrożeń dla wolności.

Pierwsza, którą wszyscy w Polsce dobrze znali, wiązała się z ograniczeniem wolności sumienia i wyznania. Druga natomiast - jak mówił papież - „płynie z cywilizacji całkowicie zeświecczonej, z cywilizacji, z ideologii głoszącej życie ludzkie bez Boga, propagującej taki sposób bycia człowieka na tej ziemi, człowieka i społeczeństwa, jak gdyby Bóg nie istniał. I to znajduje swoje odzwierciedlenie w krajach skądinąd wolnych, w nadużyciu wolności, w różnych przekroczeniach 
prawa Bożego, zwłaszcza gdy chodzi o poszanowanie życia, świętości małżeństwa, gdy chodzi o całą tę delikatną dziedzinę stosunku mężczyzny i kobiety, dziedzinę, która winna być oparta na poczuciu największej godności człowieka na obraz i podobieństwo Boże, a która jest redukowana w mentalności współczesnej, utylitarystycznej, permisywistycznej, w ten sposób, że już dla tej godności naprawdę nie ma miejsca. I często czyni się to w imię wolności człowieka”.

Dla wielu słowa Jana Pawła II dziwnie brzmiały w tamtym miejscu i w tamtym czasie. Papież przestrzegał Polaków przed pułapkami tzw. wolnego świata, który jawił się im jako coś nieosiągalnego w perspektywie pokoleń. Nie tylko zresztą im. W trwałość systemu komunistycznego wierzyła wówczas cała niemal elita polityczna Zachodu, od prawicy po lewicę. Niezależnie od tego, jak oceniano realny socjalizm, uważano, że jest on zjawiskiem nienaruszalnym na geopolitycznej mapie globu. Papież widział jednak dalej.

Kiedy dwa lata później ustrój komunistyczny w Europie Środkowej załamał się, zapanowała radość. Francis Fukuyama ogłosił „koniec historii”. Oto spełnić się miał wielki sen Immanuela Kanta o „wieczystym pokoju”. Jan Paweł II nie uległ jednak tej euforii. Kiedy w maju 1991 r. odwiedził Fatimę, przestrzegł, że marksizm może zostać wkrótce zastąpiony przez nową wersję ateizmu, która z jednej strony będzie głosić wolność, a z drugiej dążyć do zniszczenia korzeni moralności ludzkiej i chrześcijańskiej.

Niedługo potem, w książce „Przekroczyć próg nadziei”, odpowiadając na pytania Vittorio Messoriego, papież mówił, że krach ustroju marksistowskiego nie oznacza automatycznie świetlanej przyszłości: „Upadek komunizmu otwiera przed nami wsteczną perspektywę typowego myślenia i działania nowoczesnej cywilizacji, zwłaszcza europejskiej, która komunizm zrodziła. Obok niewątpliwych osiągnięć na wielu polach jest to również cywilizacja wielu błędów, a także nadużyć w stosunku do człowieka, wyzyskiwania go na różne sposoby. Cywilizacja, która wciąż przyobleka się w struktury siły i przemocy zarówno politycznej, jak i kulturalnej (zwłaszcza środki masowego przekazu), ażeby te błędy i nadużycia narzucić całej ludzkości. (...) Jakże inaczej wytłumaczyć rosnącą wciąż przepaść między bogatą Północą a coraz biedniejszym Południem? Kto jest za to odpowiedzialny? Odpowiedzialny jest człowiek, ludzie, ideologie, systemy filozoficzne. Powiedziałbym, odpowiedzialna jest walka z Bogiem, systematyczna eliminacja wszystkiego, co chrześcijańskie, która w znacznej mierze zdominowała myślenie i życie Zachodu od trzech stuleci. Marksistowski kolektywizm jest tylko «gorszym 
wydaniem» tego właśnie programu. Można powiedzieć, że dzisiaj program ten odsłania cały swój niebezpieczny charakter, a równocześnie wszystkie swoje słabości".

Te słowa mogły wielu szokować. Zdaniem Jana Pawła II komunizm był tylko „gorszym wydaniem” pewnego programu, który właśnie teraz (a było to, przypomnijmy, zaledwie kilka lat po upadku Związku Sowieckiego) „odsłania cały swój niebezpieczny charakter".

Ta diagnoza rozmijała się z odczuciami dużej części elit w krajach, które właśnie zrzuciły jarzmo realnego socjalizmu. Choć właściwie należałoby powiedzieć, że było to rozejście się nie tylko z odczuciami elit, ale nawet całych społeczeństw, które po upadku komunizmu zachłysnęły się nieznanymi im dotąd swobodami. Porównywanie demokracji liberalnej do minionego ustroju wydawało się niedorzeczne. Zniknął przecież system monopartyjny, wszechwładza bezpieki czy cenzura, a pojawiła się wolność słowa, sumienia, stowarzyszania się, zgromadzeń, prowadzenia działalności gospodarczej, podróżowania itd. Były to rzeczy oczywiste, którym trudno zaprzeczyć. Dlatego część komentatorów kwitowała słowa Jana Pawła II krótkim stwierdzeniem, że naznaczony życiem w komunizmie po prostu nie rozumie demokracji.

Sam papież odczuł to wyraźnie podczas swej wizyty w Polsce w 1991 r. Był co prawda tak jak poprzednio witany owacyjnie przez tłumy rodaków, ale w mediach pojawiła się wyraźna krytyka jego nauczania. Podczas poprzednich pielgrzymek, jeszcze w czasach peerelowskich, nawet dziennikarze reżimowi nie dopuszczali się takich ataków jak, dwa lata po upadku komunizmu, publicyści lewicowo-liberalni. Jan Paweł II wyzna to później Vittorio Messoriemu: „Kiedy podczas ostatnich odwiedzin w Polsce wybrałem jako temat homilii Dekalog oraz przykazanie miłości, wszyscy polscy zwolennicy «programu oświeceniowego» poczytali mi to za złe. Papież, który stara się przekonać świat o ludzkim grzechu, staje się dla tej mentalności persona non grata”.

Z czasem jednak zaczęły pojawiać się głosy, które współbrzmiały z intuicjami i refleksjami Jana Pawła II. Nie były one głośno komentowane w mediach głównego nurtu. Starano się je przemilczeć i nie roztrząsać. Trudno je wszakże zupełnie zignorować, ponieważ należały one do osobistości uznawanych za autorytety, na dodatek mające za sobą doświadczenie konfrontacji z komunizmem. Posiadały one jeszcze jedną wspólną cechę, która mogła wzbudzić konsternację, mianowicie 
nie były kojarzone z chrześcijaństwem. Kiedy krytyka demokracji liberalnej rozbrzmiewała z ust Jana Pawła II czy wcześniej Aleksandra Sołżenicyna, choćby podczas jego słynnej mowy harwardzkiej, zawsze można było ją zbyć żachnięciem, że to wyraz religianctwa czy klerykalizmu. Cóż jednak począć z wypowiedziami Milana Kundery, Vaclava Havla, czy Władimira Bukowskiego?

W 1993 r. w wywiadzie dla „Le Monde” Kundera powiedział zaskakujące słowa: „Drugi przesąd to przekonanie, że świat komunistyczny i świat demokratyczny są sobie absolutnie przeciwstawne. Być może przeciwstawiają się sobie z politycznego lub z ekonomicznego punktu widzenia. Ale dla pisarza punktem wyjścia jest konkretne życie konkretnego człowieka, a z tego punktu widzenia pomiędzy oboma tymi światami istnieją fascynujące podobieństwa. (...) Zrozumiałem, że komunizm ukazywał mi, w wyolbrzymionej, karykaturalnej formie, wspólne cechy nowoczesnego świata. Ta sama wszechobecna, wszechmocna biurokracja. Walka klas zastąpiona przez arogancję instytucji wobec petenta. Degradacja fachowości i rzemiosła. Infantylność oficjalnych wystąpień. Stadna organizacja wakacji. Brzydota wsi, na której zanikły wszelkie ślady gospodarskiej ręki. Uniformizacja. I najgorsza z tych wspólnych cech: brak szacunku dla jednostki i dla jej życia prywatnego. (...) Z tego punktu widzenia doświadczenie komunizmu wydaje mi się doskonałym w prowadzeniem w nowoczesny świat jako taki; uwrażliwiło mnie ono na absurdalne zjawiska, które tu gotowi jesteśmy uznać za niewinny banał lub za nieodzowne atrybuty Świętej Demokracji”.

Vaclav Havel zauważał z kolei, że istotą obu systemów jest depersonalizacja człowieka, który staje się obiektem manipulacji przez propagandę i nacisku przez biurokrację. W demokracji liberalnej dokonuje się to jednak w sposób bardziej subtelny i wyrafinowany. Jak pisał wybitny dramaturg, były dysydent i prezydent Czech: „nieprawość założyła jedwabne rękawiczki i porzuciła swe legendarne sale tortur, zamieniając je na okazałe biura anonimowych biurokracji”.

Jeszcze ostrzej swe spostrzeżenia formułował Władimir Bukowski, który mówił wprost, że Unia Europejska jest niczym innym jak nowym wcieleniem Związku Sowieckiego, owego straszliwego więzienia narodów, tylko w bardziej nowoczesnej, a przez to podstępniejszej wersji.

Trudno oskarżać autorów powyższych wypowiedzi o niezrozumienie istoty totalitaryzmu bądź jego banalizację, skoro - jak Sołżenicyn czy Bukowski - doświadczyli na sobie grozy komunizmu w jego najpotworniejszym wydaniu. Na czym 
wobec tego opiera się owa nieoczywista na pierwszy rzut oka teza o podobieństwie komunizmu i liberalnej demokracji?

Można powiedzieć, że wspólny pozostaje dla nich mit prometejski. U źródeł obu ideologii tkwi bowiem to, co Chantal Delsol nazywała „nienawiścią do świata”, przekonanie o dogłębnym zepsuciu otaczającej nas rzeczywistości. Z tą ponurą diagnozą wiąże się postulowane remedium: konieczność naprawy zastanego świata, a więc przebudowy go w imię postępu i emancypacji ludzkości. W celu wyzwolenia człowieka ze zniewalających go ograniczeń należy zburzyć dotychczasowy porządek. Dobrze ujmowały to słowa „Międzynarodówki” rozbrzmiewające niemal na całym globie: „Przeszłości ślad dłoń nasza zmiata”. I rzeczywiście dłonie rewolucjonistów zmiatały stary świat wraz z jego filarami: religią (określaną jako „opium dla ludu”), własnością prywatną, czy tradycyjną moralnością (nazywaną mieszczańską lub burżuazyjną). W imię wyzwolenia ludzkości wymordowano ponad sto milionów ludzi i zbudowano najbardziej monstrualny system niewoli, terroru oraz kłamstwa, jaki zaistniał kiedykolwiek w historii.

Choć ustrój komunistyczny skompromitował się i upadł w licznych krajach, to jednak ożywiające go marzenie nie umarło. Co więcej, stało się ono najbardziej żywotną i dynamiczną ideą demokracji liberalnej. Było coś zadziwiającego w obserwowaniu, jak szybko i bezboleśnie niedawni jeszcze aparatczycy komunistyczni przedzierzgali się we wzorowych liberałów. Emblematyczną postacią dla tego procesu stał się Zygmunt Bauman, który przetarł drogę całemu pokoleniu neofitów - zarówno w wymiarze biograficznym (od pułkownika Korpusu Bezpieczeństwa Wewnętrznego do profesora Uniwersytetu w Leeds), jak też ideowym (od stalinizmu do postmodernizmu). Jego naśladowcy przejmowali ten sam schemat jedynej słusznej monopolistycznej idei, swoistą nowomowę oraz wrogość wobec przeciwników politycznych, którzy - zarówno na pierwszym, jak i drugim etapie mądrości - jakimś dziwnym trafem okazywali się ci sami i mieli tak samo nieodwołalnie wylądować na śmietniku historii. Było w łatwości tej metamorfozy coś, co kazało zadumać się nad wspólnotą założeń oraz ideałów tych obu na pozór nie przystających do siebie systemów.

Łączyło je przede wszystkim wspomniane już pragnienie emancypacji. W demokracji liberalnej przybrało ono rozmiary jeszcze bardziej rozległe, wręcz totalne, zagarniając całe obszary życia ludzkiego, o których marksiści nie śmieli nawet pomarzyć. Dziś znów należy wyzwolić ludzkość ze wszystkiego, co ją ogranicza, ale nie wystarczy już uwolnić ją od religii chrześcijańskiej, patriarchalnej rodziny, 
tradycyjnej moralności czy państwa narodowego, ale należy wyswobodzić ją także od prawa naturalnego, płci biologicznej czy kondycji gatunkowej. Nie do przyjęcia są wszelkie stałe więzi, gdyż - jak sama nazwa wskazuje - one nas związują i więzią. Nie może być natomiast nic wiążącego: żadnych niezmiennych relacji, nieprzekraczalnych różnic czy stałych zależności, ponieważ samo ich istnienie urąga poczuciu wolności. Nawet towarzyszący ludzkości od początku istnienia podział na mężczyzn i kobiety okazuje się ograniczeniem, które należy zniszczyć.

Już Alexis de Tocqueville w połowie XIX w. zauważał, że demokracja da się z powodzeniem pogodzić z uciskiem politycznym, który będzie realizowany jednak metodami subtelniejszymi niż naga siła. Sto lat później do podobnych wniosków doszła Hannah Arendt, stwierdzając, że istotą totalitaryzmu nie jest wcale terror, lecz wykorzenienie - pozbawianie ludzi więzi i relacji.

O tym samym zjawisku myślał Jacob Leib Talmon, gdy pisał o demokracji totalitarnej, która - w odróżnieniu od komunizmu - może istnieć bez likwidacji własności prywatnej, bez masowego terroru i bez oficjalnie działającej cenzury. Kontrola sprawowana jest łagodniej: przez instytucje państwa opiekuńczego, urzędy opieki społecznej, obowiązkowe systemy ubezpieczeń, mechanizmy podatkowe, programy oświatowe, przekazy medialne. Przez przemoc symboliczną, presję moralną, niejawną perswazję, dystrybucję autorytetów, unieważnianie dyskursów, kwestionowanie prawomocności, zawstydzanie, onieśmielanie, ośmieszanie i szyderstwo.

Zbigniew Herbert w „Potędze smaku” wzdychał: „Kto wie, gdyby nas lepiej i piękniej kuszono...”. Dla jego pokolenia komunizm nie miał w sobie już nic czarującego, żadnego wdzięku czy powabu. Pokolenie żarliwych misjonarzy bolszewizmu, przypominające nowożytną wersję bohaterów „Dziejów Apostolskich”, opisywane w poemacie Aleksandra Błoka czy wspomnieniach Artura Koestlera, odeszło bezpowrotnie w przeszłość. Wzorce osobowe, jakie proponował młodym ludziom realny socjalizm, były raczej odstręczające: traktorzystki z paznokciami nie pomalowanymi lakierem, lecz wybrudzonymi czarnym smarem, albo przodownicy pracy zapadający po trzydziestce na pylicę płuc i plujący krwią - to nie mogło pociągać nikogo. Dziś programowanie uczuć i kontrola nad umysłami są dużo subtelniejsze. Kuszeniem zajmują się prawdziwi władcy wyobraźni, kreatorzy mód, nieprzypadkowo zwani - używając języka religii - idolami lub ikonami kultury.

Popkultura okazała się skuteczniejsza od agit-propu. Ryszard Legutko w książce „Triumf człowieka pospolitego” zauważał, że w liberalna demokracja stanowi 
większą mistyfikację ideologiczną niż socjalizm, ponieważ ten ostatni posługiwał się przymusem i przemocą, by zmusić ludzi do „przyjęcia przekonania, że jeśli zniknie wszystko, co niesocjalistyczne, to będzie to korzystniejsze dla nas wszystkich. W liberalnej demokracji to sami ludzie uwierzyli, że likwidacja instytucji niezgodnych z zasadami liberalno-demokratycznymi jest krokiem rozumnym i koniecznym". W tym kierunku powinny być więc przekształcane zasady etyczne i obyczaje moralne, prawo i kultura, Kościoły i rodziny, szkoły i uniwersytety, wspólnoty i organizacje.

Ideologowie powszechnej emancypacji uważają całą rzeczywistość społeczną za zmienną, plastyczną i negocjowalną. Wszystko, co da się pomyśleć, da się też zrobić, a skoro tak jest, to należy to uczynić. Na tym polega przecież wolność. Są więc oni niczym demiurgowie, którzy traktują społeczeństwa nie jak organizmy rządzące się swoimi prawami, lecz jak mechanizmy, które można rozkładać na czynniki pierwsze, by następnie konstruować je na nowo w dowolnych konfiguracjach. Są jak bogowie, którzy stwarzają światy na nowo.

Historia uczy jednak, że po zdekonstruowaniu wszystkich relacji i więzi na końcu zawsze wychodzi tyrania. Kiedyś było to państwo komunistyczne, dziś na naszych oczach powstaje państwo opatrznościowe. Ma ono wręcz uroszczenia teokratyczne, uzurpując sobie prawo do wiązania ludzkich sumień. To ono decyduje, co jest dobrem, a co złem. Ono wie nawet lepiej, co człowiek powinien myśleć. Oczywiście wszystko dzieje się w imię wolności, ale to państwo lepiej niż pojedynczy człowiek rozumie, na czym polega wolność i jak może on ją w swym życiu urzeczywistnić.

$\mathrm{Na}$ takiej podstawie w niektórych państwach nie można zostać ginekologiem, jeśli nie przeprowadzi się aborcji (jak w Kanadzie), nie można uchronić swych dzieci przed deprawacją seksualną w szkołach połączoną z propagowaniem ideologii gender (jak w Niemczech), nie można prowadzić domów adopcyjnych, jeśli wyklucza się pary jednopłciowe jako rodziny zastępcze (jak w Wielkiej Brytanii), nie można pod groźbą kary więzienia rozpowszechniać publicznie informacji o negatywnych skutkach aborcji (jak we Francji). Rocco Buttiglione nie został komisarzem w Unii Europejskiej tylko dlatego, że podzielał nauczanie Kościoła w sprawie homoseksualizmu. Elity unijne potraktowały to jako „myślozbrodnię”.

W takim ujęciu polityka nie jest rozumiana jako narzędzie rozwiązywania konkretnych problemów, przed którymi staje dana społeczność, lecz jako aktywność dążąca do osiągnięcia celów ostatecznych człowieka. W niej ma znaleźć swe 
eschatologiczne wypełnienie cała historia ludzkości. Na tym polega najgłębsze podobieństwo między komunizmem a współczesną ideologią emancypacyjną demokracji liberalnej. Są one świeckimi religiami, które oferują ludziom zbawienie w doczesności. Można je nazwać - za Erikiem Voegelinem - gnozą polityczną, która dokonuje „immanentyzacji eschatonu”. Sam twórca tego pojęcia zaliczył zresztą do owej kategorii nie tylko marksizm i narodowy socjalizm, lecz także liberalizm. W „Nowej nauce polityki” pisał: „jeżeli liberalizm oznacza wewnątrzświatowe zbawienie człowieka i społeczeństwa, to komunizm jest jego najbardziej radykalnym wyrazem".

Pod tym zdaniem z pewnością mógłby się podpisać Jan Paweł II, który mówił, że „marksistowski kolektywizm jest tylko «gorszym wydaniem» tego właśnie programu". W encyklice Centessimus annus papież pisał, że komunizm upadł na skutek obecnego w nim „błędu antropologicznego”, polegającego m.in. na stawianiu wolności w opozycji do prawdy. Podobny gen autodestrukcji zawiera w sobie ideologia liberalnej demokracji. Otwarte pozostaje tylko pytanie, jaki krajobraz pozostawi po sobie, gdy w końcu wyczerpie swe siły witalne. 